\title{
Effect of Heat Input on Microstructure and Corrosion Behavior of High Strength Low Alloy Steel Welds
}

\author{
Hua Qin ${ }^{1, *}$, Yingchun Tang ${ }^{2}$, Ping Liang ${ }^{1}$ \\ ${ }^{1}$ School of mechanical engineering, Liaoning Shihua University, Fushun 113001, China; \\ ${ }^{2}$ Sino- German Institute of Shengyang Polytechnic College, Shenyang 110045, China. \\ "E-mail: huaq2008@163.com
}

doi: $10.20964 / 2021.04 .07$

Received: 14 November 2020 / Accepted: 12 January 2021 / Published: 28 February 2021

\begin{abstract}
High strength low alloy (HSLA) steel was welded by metal active gas arc welding (MAG), and the effect of heat input on microstructure and corrosion behavior of HSLA welds was investigated by optical microscope $(\mathrm{OM})$, scanning electron microscopy (SEM), potentiodynamic polarization curves, electrochemical impedance spectroscopy (EIS) in this study. Results indicated that the volume percent of acicular ferrite (AF) in the weld increases first and then decreases with the increase of heat input, when the heat input is $11.9 \mathrm{~kJ} \cdot \mathrm{cm}^{-1}$, the proportion of acicular ferrite obtained in the weld reaches the maximum value. It is found that the type of microstructure has significant effect on corrosion behavior of the weld metal, the increase in the amount of acicular ferrite can result in corrosion property of the weld metal becoming worse in $3.5 \mathrm{wt} \% \mathrm{NaCl}$ solution. Moreover, the thickness and density of corrosion product on the surface of samples play a very important role in the corrosion behavior of the weld metal. When the corrosion product is loose, porous and defective, it provides minor protection for the weld metal, in this case, corrosion rate of the weld metal increases.
\end{abstract}

Keywords: HSLA steel; Heat input; Weld metal; Microstructure; Corrosion behavior

\section{$\underline{\text { FULL TEXT }}$}

(C) 2021 The Authors. Published by ESG (www.electrochemsci.org). This article is an open access article distributed under the terms and conditions of the Creative Commons Attribution license (http://creativecommons.org/licenses/by/4.0/). 